\title{
Animal and workers' welfare during agricultural fair
}

\author{
Cinara da Cunha Siqueira Carvalho (iD - Maria Dulcinéia da Costa - Maria Cecília Magalhães Gonçalves • \\ Thamara Amaral Diniz - Geruza Cardoso da Silva (iD - Heberth Christian Ferreira • \\ Kátia Cristiane Borges Pereira • Anna Luísa de Oliveira Castro • Laize Vieira Santos
}

CCS Carvalho (Corresponding author) - MD Costa - MCM

Gonçalves - TA Diniz - GC Silva - HC Ferreira - KCB

Pereira - ALO Castro

Department of Agricultural Sciences, State University of

Montes Claros (UNIMONTES), Montes Claros, MG, Brazil.

email: cinarasiqueira@yahoo.com.br

\section{Santos}

State University of Southwest of Bahia, BA, Brazil.

Received: October 10, 2018 - Revised: December 02, 2018 • Accepted: December 02, 2018

\begin{abstract}
The animal welfare concept in the last years began to be implanted in the animal production scenario and in the environment where the workers are inserted. But, the animal breeders themselves know little about rational handling, the labor laws, and the positive effects that this practice can offer. Therefore, this study aimed to characterize the physiological parameters and the welfare conditions of the animals and the workers, during an agricultural fair in the Brazilian semi-arid. Questionnaires were applied to visitors, caretakers, and farmers, in order to verify the perception level regarding the adoption of rational handling and, animal and workers' welfare. Subsequently, the handling and thermal environment were evaluated. The following physiological variables were collected: rectal and body surface temperature and, respiratory rate during shipment and landing of the beef cattle belonging to the elite category at the fair. Questionnaires data showed that the theme welfare and rational handling is known among visitors, caretakers and farmers, and that the practice is less stressful to animals. The physiological variables were within the recommended standards, indicating the animal thermoregulation and animal adaptation to the shipment, transport and landing. However, the handling adopted by the workers is still result on cultural issues, lack of information and awareness about the benefits of rational handling.
\end{abstract}

Keywords: ambience, thermal comfort, agricultural fair

\section{Introduction}

The cattle is one of the most prominent sectors of Brazilian agribusiness because of the impact on the food production, from two lucrative segments: beef and milk productive chain. Given the importance of the cattle has for Brazil, exhibitions and agricultural fairs are held all over the country as a way to spread the news of the field, the current status of production and genetics through the demonstration of these animals on the judgment track and during the conduct of auctions. Thus, the farmers, aim mainly to remain competitive and become increasingly viable activity to your own accumulation (Pereira 2011).

In this context, concern for animal welfare is increasing, including agricultural fairs, due to virtual visibility that the event has acquired over the years. Most of the animals who come to the exhibition (agricultural fair), which are intended for the auctions, are traditionally handled and the period of stay in the fair waiting for the moment the market is short. Therefore, this animals are subject to food shortages and are accommodated in premises which are devoid of protection and comfort, generate physiological stress. The opposite condition is checked for the animals, which have greater commercial value due to productivity and genetic value. The animals in an attempt to adapt the unfavorable conditions alter the physiological variables, which are measured by heart and respiratory rate and rectal temperature.

The topic "welfare" can also be used for humans from the workplace adaptation, in order to meet the standards of the "Ministério do Trabalho e Emprego", to provide these workers life quality at work (Carvalho et al 2014). Given the importance that exists around this subject, this study aimed to characterize physiological variables and animal welfare conditions, as well as of workers responsible by animal handling during agricultural fair.

\section{Materials and Methods}

The procedures performed in this experiment were approved by the Ethics Committee on Animal Experimentation and Welfare of the Universidade Estadual de Montes Claros under registration $n^{\circ} 060 / 2013$ and Process $n^{\circ}$ 173.439 by the Ethics Committee on Research - Human. 
The data collection took place during two consecutive years in agricultural fair located in the Brazilian semi-arid. Data collection was divided into two parts: the first with characterization of the farmers perception, workers and visitors, regarding the rational handling and welfare of the animals and workers through the application of questionnaires. The second part was composed of environmental, physiological and behavioral assessments of the animals and workers, as well as the in loco observation of the handling type adopted for the commercial and elite animals, during the landing, shipment and the period that remained in the exhibition area.

The physiological and behavioral responses of twenty one Nellore animals were evaluated in the following instants: before shipment (when they were on the farm); arrival at the exhibition park (after landing); and, in the exhibition park (before shipment back to the farm). The physiological responses were characterized by obtaining the respiratory rate, rectal and body surface temperature. The data collected were analyzed according to the age and sex of the animals. Respiratory rate was measured by the visualizing the flank movements on the right side of the animal during one minute. Body surface temperature was measured on in the dorsal region using an infrared thermometer (Instrutemp, model ITTI 550). Rectal temperature was measured using a digital clinical thermometer, inserted directly into the rectum, remaining until the moment the sensor emitted a beep.

Daily, the air temperature, dew point temperature and black globe temperature; relative humidity, wind speed, noise and water temperature consumed by cattle were collected from 08:00 to 18:00. These data were collected in the waiting pens for the auctions and the exhibition halls of the animals. The values of temperature and relative humidity of the air were collected by means of a Data Logger of humidity and temperature (Extech ${ }^{\circledR}$, model RTH10). The equipment was programmed to perform data collection every 30 minutes and was installed near the animal location bays at $1.60 \mathrm{~m}$ height. The Black Globe Humidity Index (WBGT) proposed by Buffington et al (1981) was calculated for each constructive typology using the equation 1 .

$\mathrm{BGHI}=\mathrm{Tgn}+0,36 \mathrm{Tpo}+41,5$

where BGHI is the Black globe-humidity index (BGHI), Tgn is the black globe temperature $\left({ }^{\circ} \mathrm{C}\right)$ and $\mathrm{Tpo}=\mathrm{Dew}$ point temperature $\left({ }^{\circ} \mathrm{C}\right)$.

In order to verify the noise level, a digital decibelmeter (Instrutherm, model DEC-490) measuring sound level with an accuracy of $\pm 1,5 \mathrm{~dB}$ was used. Wind speed was collected through portable digital anemometer (Instrutherm, model AD 250). Both were collected every two hours and, on days when musical show took place, the noise intensity was collected until 10:00 p.m.
The temperature of the water in the drinking fountains in the corral where the animals destined for the auction were housed and the water offered to the elite animals housed in the exhibition halls was measured every two hours daily using a digital spit thermometer.

Regarding the handling, we accompany the shipment and landing process of 30 lots of Nelore cattle that arrived at the fair to be exhibited in judgment and auction runways. The elite animals were led to individual bays, characterized of concrete floor and coated with litter of rice straw. Water was frequently supplied and diet based on sorghum silage and corn grain, was provided by property handlers as needed. The animals destined to the auction were accommodated in collective bays, without system of cover, that is, exposed to direct solar radiation and wind. The feed was restricted and the water was in concrete troughs. The animals destined to the auctions were zebu brought from farms to approximately 40 $\mathrm{km}$ of distance and they remained in corrals, for an average period of 12 hours.

During the auction, animals lots were driven by auctioneers to the closing track, and during the bids were handled by a horse-mounted employee. At each animals lots entry, the handling and animal behavior were observed, as well as the noise level during the stay time on the track.

The workers' welfare condition was characterized by observations about the place where they were housed, to the food and bathroom accessibility, and the satisfaction level with the activities developed.

The questionnaire applied to visitors, handlers and farmers sought to identify the following aspects, which are presented in Table 1.

The questionnaires and environmental variables were submitted to descriptive statistics, where the quantitative variables represented as percentage (\%). For the physiological variables, the animals were divided by sex (males and females) and age (two age groups: <24 months and> 24 months). We performed an analysis of variance and the significant differences between the means were obtained by the $\mathrm{F}$ test $(\mathrm{P}<0.05)$ for the sex and age categories. We used the Tukey test $(\mathrm{P}<0.05)$ to verify differences between the evaluation periods (farm and exhibition park). In addition, the environmental variables related to the comfort condition of workers were confronted with the Regulatory Norms 15 and 17 of the Ministério do Trabalho e Emprego (2007).

\section{Results and Discussion}

Eighty-eight visitors were interviewed at the agricultural fair, and of these, $33 \%$ did not know or had never heard about the rational handling practices. The remaining (67\%) reported that adopting rational handling or animal welfare good practices throughout the breeding process could lead to a higher life quality for animals. In addition, the 
majority of visitors $(88 \%)$ believe that the adoption of these practices can cause less stress to the animals and consequently improve the meat quality.

Regarding animal husbandry, $67 \%$ of the interviewees know the system and $97 \%$ admit the importance of animals having easy access to food, water, and walking space, factors that are recommended by animal welfare protocols. During the visit to the agricultural fair, it was questioned if the visitors observed if any animal was restless and if the handler shouted or attacked the animals. This was observed by $36 \%$ of the interviewees, $58 \%$ would feel uncomfortable and $6 \%$ reported that they would be indifferent.

Table 1 Profile, characterization and, public, farmers and handlers opinion, regarding animal welfare practices.

\begin{tabular}{ll}
\hline Observed factors & Interviewees' opinion \\
\hline $\begin{array}{l}\text { Identification } \\
\text { Reason for visit to the fair }\end{array}$ & $\begin{array}{l}\text { Age, schooling and profession } \\
\text { Entertainment and leisure, animal purchase, work, amusement park, } \\
\text { business opportunity, auctions or gastronomy } \\
\text { Body condition score, origin, cleanliness, reactivity and injuries }\end{array}$ \\
$\begin{array}{l}\text { Appearance observed in the } \\
\text { animals }\end{array}$ & $\begin{array}{l}\text { Knowledge and the technique application, ease in herd handling, } \\
\text { Rational handling opinion }\end{array}$ \\
$\begin{array}{l}\text { Animal handling during the promotion and maintenance guarantee of meat quality } \\
\text { agricultural fair }\end{array}$ & $\begin{array}{l}\text { Importance of feed and water access and space for animals to hike } \\
\text { Public reaction } \\
\text { Meat purchase }\end{array}$ \\
$\begin{array}{l}\text { The fact that the animal was bred according to the premises of } \\
\text { rational or aversive handling, would choose one of the two or did not } \\
\text { make any difference at the purchase moment } \\
\text { Observation made by the interviewees about the place of handlers } \\
\text { accommodation }\end{array}$ \\
\hline
\end{tabular}

During the auction of animals, twenty-four visitors were interviewed. When asked about the reason for the visit to the agricultural fair, $88 \%$ answered that they participated in exposure to work or business and $12 \%$ reported having other interests. After being asked what they observed most in the animals during the auction. $50 \%$ were attentive to the animals' body score, $46 \%$ observed the breed characteristics and only $4 \%$ of the farmers observed the price of the animals.

When asked about knowledge about rational handling or adoption of animal welfare practices, only $4 \%$ were unaware of these practices and $96 \%$ had knowledge. For most, good handling practices are of fundamental importance for offering a better life quality to the animals, resulting in greater gains in productivity.

Farmers also believe that the adoption of these practices can result in less stress on the animal and consequently improvement in weight gain, meat quality and the benefit of commercialization. However, many of them do not adopt these handling techniques on their farm due to the difficulty in having access to training for their handlers. For the remaining $4 \%$, significative results in weight gain are related to good grazing and feed supplementation, not to the animal handling modification.

During the auction, for $79 \%$ of interviewed, if the animals are scared or injured, this may interfere with the purchase decision. According to Chiquitelli Neto (2005), what is possible to observe nowadays is that the way the animals are handled catches the public attention that participates in the auctions transmitted by tv or virtual (by internet). $79 \%$ of farmers feel uncomfortable when the handlers shout and are aggressive the animals during the auction, while for $21 \%$ this only draws attention and $8 \%$ are indifferent to this.

Thirty-nine questionnaires were applied to handlers to check their perception level regarding the adoption of practice of workers' and animal welfare. 87\% have heard of animal welfare practices and believe this practice can cause less stress to the animal and therefore improve weight gain, the meat quality and make commercialization more favorable.

The data collected showed that $100 \%$ of the handlers are aware that it is important that animals have easy access to feed, water and walking during the period they are at the agricultural fair. When they are responsible for handling elite animals, these actions are carried out naturally. However, the handling adopted with the commercial animals destined to the auction follows the conventional concept, in which the access to feedd is restricted, the water is offered ad libitum, but without sanity care, and the movement is limited between the pier and the corral of the agricultural fair.

According to Gregory and Grandin (1998), humans have responsibility for the animals suffering. Information and training lack generate an inability to perform the tasks and disregard or lack of care to animals.

Concerning these handlers' welfare, it was verified that $100 \%$ of the interviewed sleep less than 8 hours per day. 
Marçal (1996) in an educational work to prevent animal problems in agricultural exhibitions, noted the occurrence of problems with the digestive system of cattle, due to the excessive fatigue of the handlers during the event. This induces handlers to errors, such as: leaving the food already cut days before making it available to the animals; an exaggerated amount offered to reduce time intervals between the food supplies, besides the little animal exercise, such as walking through the agricultural fair. $O$ fornecimento de condições adequadas de trabalho e acomodação para os trabalhadores, além do treinamento e conscientização de suas ações, reflete satisfatoriamente no manejo com os animais (Carvalho et al 2011).

It was also sought to know these workers' satisfaction level. It was possible to verify that, even with the intense work, the few hours of sleep and the privacy absence, since they are accommodated in trucks or in individual tents in front of the pavilions where the animals are housed, these workers enjoy the activity and do not see themselves doing another work type. This fact reflects the proposed theory Brief and Weiss (2002), where this feeling is considered an attitude formed by affective components, that is, the pleasure and joy in developing a certain activity.

During the observations made at the place where the shipment and landing of the animals takes place, a concrete ramp has been constructed with soft steps to avoid animals' sliding and possible falls. The ramp was surrounded with plain wire and, at the end, the animals passed by the footbath, which was composed of lime and water, replenished daily or as needed.

All batches of animals, upon arriving at the agricultural fair, were evaluated to see if they had not been injured during the transport or if they were sick. For each batch, the vaccination record for anemia and glanders was also evaluated, in order to meet general and specific health requirements. $57 \%$ of the observed batches were handled with jerks, screams or shocks. The other lots were conducted in a calm manner, without any practice that could stress the animals.

Regarding the meteorological conditions, an average air temperature of $31.8^{\circ} \mathrm{C}$ (minimum of $27.4^{\circ} \mathrm{C}$ and maximum $35.6^{\circ} \mathrm{C}$ ) was verified. The average relative humidity was $44.9 \%$ (minimum $36.9 \%$ and maximum $54.9 \%$ ). With regard to workers, NR-17 states that the work environmental temperature when it exceeds the normal skin temperature (30 $-35^{\circ} \mathrm{C}$ ) can cause mental fatigue and physical exhaustion. The mean values of air temperature close to $35^{\circ} \mathrm{C}$ were verified at 12:00, however, this meteorological condition during the experimental period is not a factor that exposes the workers to a thermal discomfort due to the season in which the agricultural fair occur.

The physiological variables analysis shows, in Table 2, for the body surface temperature $\left(\mathrm{BST},{ }^{\circ} \mathrm{C}\right)$, that there was an interaction between the sex category and the observation location, where the lowest BST values were verified during shipment at the farm, for the males and females. This fact is due to waiting for the shipment to occur until 10:00 and in a shaded corral. In this way, the shading reduced the absorption of heat from the direct solar radiation.

The highest values of BST verified on the agricultural fair arrival were due to the transport time ( 3 hours and 15 minutes), where the animals received direct solar radiation, being dissipated through by the cover cracks of the truck and during arrival time. The first landing took place between 13:00 and 14:00 and the second between 18:00 and 19:00. Some of these animals remained inside the truck for about 8 hours under direct solar radiation. During the shipment in the agricultural fair to the farm, which occurred at 12:00, the animals waited for shipment in the corrals with few shading being exposed to solar radiation. These high levels of direct solar radiation were still associated with high air temperature values, which culminated in the BST elevation in both males and females. BST values in the different categories and locations were within the thermal comfort range of $27.7^{\circ} \mathrm{C}$ and $46.3{ }^{\circ} \mathrm{C}$ (Ferreira et al 2006).

There was a significant difference $(\mathrm{P}<0.05)$ between the locations for respiratory rate (RR). The highest RR values were verified during the agricultural fair arrival. This fact is due to the waiting time inside the truck ( 8 hours), transport time ( 3 hours and 15 minutes) and arrival at an unknown location. Long-distance transport can cause psychological stress when the animals are submitted to a new environment and to new handling, as well as the physical stress coming from fatigue, unfavorable thermal conditions and feed restriction (Grandin, 1997). Regarding the sex, there was no significant difference for RR. According to Hahn and Mader (1997), RR values of 60 breaths/min indicate animals without thermal stress. In the present study, it was verified that RR values of elite Nelore cattle did not exceed comfort values.

Table 2 shows that there was a significant interaction $(\mathrm{P}<0.05)$ between the location and the sex for the RT. There was no difference between males and females during arrival in the agricultural fair and departure from the farm At departure from the farm, the males presented RT similar to the females when evaluated during the departure of the agricultural fair. The mean values of RT as a function of location and sex were within the thermal comfort described by Robinson (1999), where the bovine rectal temperature can range from $38.1{ }^{\circ} \mathrm{C}$ to $39.1{ }^{\circ} \mathrm{C}$ for specialized Nellore breed.

Because the animals did not present BST and RR outside the comfort zone, it demonstrated the fact that there was no excess body heat stored, because the RT was within normal levels. Analyzing the BST averages (Table 3), there was a difference $(\mathrm{P}<0.05)$ between the locations, with the highest values observed in the departure of the agricultural 
fair. Likewise, the RR averages were higher in this same location (Table 2).

There was no significant difference $(\mathrm{P}>0.05)$ between males and females for RR. Silva et al (2005) working with beef cattle, males and females aged 12 and 24 months, between October and December, did not find significant effect (P> 0.05) of age on RR, with 22.42 breaths. min $^{-1}$ for animals at 12 months and 22.54 breaths. min $^{-1}$ for animals at 24 months of age. Grandin (1997) reports that younger animals suffer more from the stressors effects due to less previous experience, but this information was not verified in the present study.

Regarding RT, it was verified that there was a significant difference $(\mathrm{P}<0.05)$ in the animals when comparing locations, since the highest values were found on arrival at the agricultural fair, due to tiredness caused by transport time.

Table 2 Mean values of the body surface temperature $\left(\mathrm{BST},{ }^{\circ} \mathrm{C}\right)$, respiratory rate $\left(\mathrm{RR}\right.$, breaths.min $\left.{ }^{-1}\right)$ and rectal temperature $\left(\mathrm{RT},{ }^{\circ} \mathrm{C}\right)$ as a function of the observation site and sex.

\begin{tabular}{llcl}
\hline \multicolumn{2}{c}{ Body surface temperature } & \\
\hline Location & Males & Females & Mean \\
\hline Departure from the farm & $30.5^{\mathrm{B}}$ & $30.7^{\mathrm{B}}$ & $30.6^{\mathrm{C}}$ \\
Arrival at the agricultural fair & $32.4^{\mathrm{A}}$ & $33.1^{\mathrm{A}}$ & $32.7^{\mathrm{B}}$ \\
Departure of the agricultural fair & $33.6^{\mathrm{A}}$ & $35.1^{\mathrm{A}}$ & $34.2^{\mathrm{A}}$ \\
Mean & 32.1 & 32.0 & \\
$\mathrm{CV}(\%)$ & & & \\
\hline
\end{tabular}

\begin{tabular}{|c|c|c|c|}
\hline \multicolumn{4}{|c|}{ Respiratory rate } \\
\hline Departure from the farm & 40.3 & 40.5 & $40.3^{\mathrm{B}}$ \\
\hline Arrival at the agricultural fair & 46.0 & 49.0 & $47.1^{\mathrm{A}}$ \\
\hline Departure of the agricultural fair & 43.7 & 46.0 & $44.1^{\mathrm{AB}}$ \\
\hline Mean & 43.3 & 45.1 & \\
\hline $\mathrm{CV}(\%)$ & \multicolumn{2}{|c|}{10.3} & \\
\hline \multicolumn{4}{|c|}{ Rectal temperature } \\
\hline Departure from the farm & $38.1^{\mathrm{bB}}$ & $38.9^{\mathrm{aA}}$ & 38.4 \\
\hline Arrival at the agricultural fair & $38.8^{\mathrm{aA}}$ & $38.9^{\mathrm{aA}}$ & 38.8 \\
\hline Departure of the agricultural fair & $38.7^{\mathrm{bA}}$ & $38.0^{\mathrm{aB}}$ & 38.5 \\
\hline Mean & 38.5 & 38.6 & \\
\hline $\mathrm{CV}(\%)$ & \multicolumn{2}{|c|}{1.37} & \\
\hline
\end{tabular}

Azevêdo et al (2008) evaluated cattle in the dry and rainy season, with two age categories (adults and young animals), found that young animals had higher RT than adults in both dry and rainy season. The RT evaluated in the present study was within the comfort range for cattle over one year old $\left(38.5{ }^{\circ} \mathrm{C}\right)$, proposed by Kolb (1987). This indicates that there was physiological resistance of the Nellore cattle (Elite category) to the environmental conditions provided by transport, waiting period and accommodation sites.

In the present study, animals aged $<24$ months presented BST, RR and RT values similar to animals $>24$ months, since there was no significant difference $(\mathrm{P}>0.05)$ between these ages.
Concerning the noise level, it was verified that during all the observation days, the values were below the maximum limits recommended by the welfare protocol for animals and humans. However, during the days of shows, the average noise was $88 \mathrm{~dB}(\mathrm{~A})$, with a maximum value of $98 \mathrm{~dB}(\mathrm{~A})$. These values were above the standards recommended by NR-15 (2004), which recommends maximum exposure of $85 \mathrm{~dB}$ (A) for 8-hour of work.

As regards wind speed, the animals that were housed in the corral were exposed to a higher wind intensity (3.0 to $\left.4.5 \mathrm{~m} . \mathrm{s}^{-1}\right)$ when compared to the conditions observed in the pavilion (1.8 to $3.8 \mathrm{~m} \cdot \mathrm{s}^{-1}$ ). This occurred due to the absence of 
surrounding landscaping that would act as a natural barrier, providing greater comfort to the animals housed (Figure 1).

Table 3 Mean values of the body surface temperature $\left(\mathrm{BST},{ }^{\circ} \mathrm{C}\right)$, respiratory rate $\left(\mathrm{RR}\right.$, breaths. $\left.\mathrm{min}^{-1}\right)$ and rectal temperature $(\mathrm{RT}$, ${ }^{\circ} \mathrm{C}$ ) as a function of the age and observation site.

\begin{tabular}{|c|c|c|c|}
\hline Location & $\leq 24$ months & $>24$ months & Mean \\
\hline \multicolumn{4}{|c|}{ Body surface emperature } \\
\hline Departure from the farm & 32.1 & 31.6 & $32.0^{\mathrm{B}}$ \\
\hline Arrival at the agricultural fair & 33.3 & 33.5 & $33.4^{\mathrm{AB}}$ \\
\hline Departure of the agricultural fair & 33.5 & 34.2 & $33.8^{\mathrm{A}}$ \\
\hline Mean & 33.0 & 33.1 & \\
\hline $\mathrm{CV}(\%)$ & \multicolumn{2}{|c|}{7.3} & \\
\hline \multicolumn{4}{|c|}{ Respiratory rate } \\
\hline Departure from the farm & 41.2 & 40.4 & $40.8^{\mathrm{B}}$ \\
\hline Arrival at the agricultural fair & 48.3 & 45.6 & $47.1^{\mathrm{A}}$ \\
\hline Departure of the agricultural fair & 44.3 & 45.8 & $45.0^{\mathrm{AB}}$ \\
\hline Mean & 44.7 & 43.9 & \\
\hline $\mathrm{CV}(\%)$ & \multicolumn{2}{|c|}{11.6} & \\
\hline
\end{tabular}

\begin{tabular}{|c|c|c|c|}
\hline \multicolumn{4}{|c|}{ Rectal temperature } \\
\hline Departure from the farm & 38.5 & 38.3 & $38.4^{\mathrm{B}}$ \\
\hline Arrival at the agricultural fair & 39.0 & 38.6 & $38.8^{\mathrm{A}}$ \\
\hline Departure of the agricultural fair & 38.7 & 38.6 & $38.6^{\mathrm{AB}}$ \\
\hline Mean & 38.7 & 38.5 & \\
\hline $\mathrm{CV}(\%)$ & \multicolumn{2}{|c|}{1.4} & \\
\hline
\end{tabular}

Uppercase letters differ in the column (for location) and lowercase letters differ from each other in the row (for age), Tukey test $(\mathrm{P}<0.05)$. CV: Coefficient of variation.

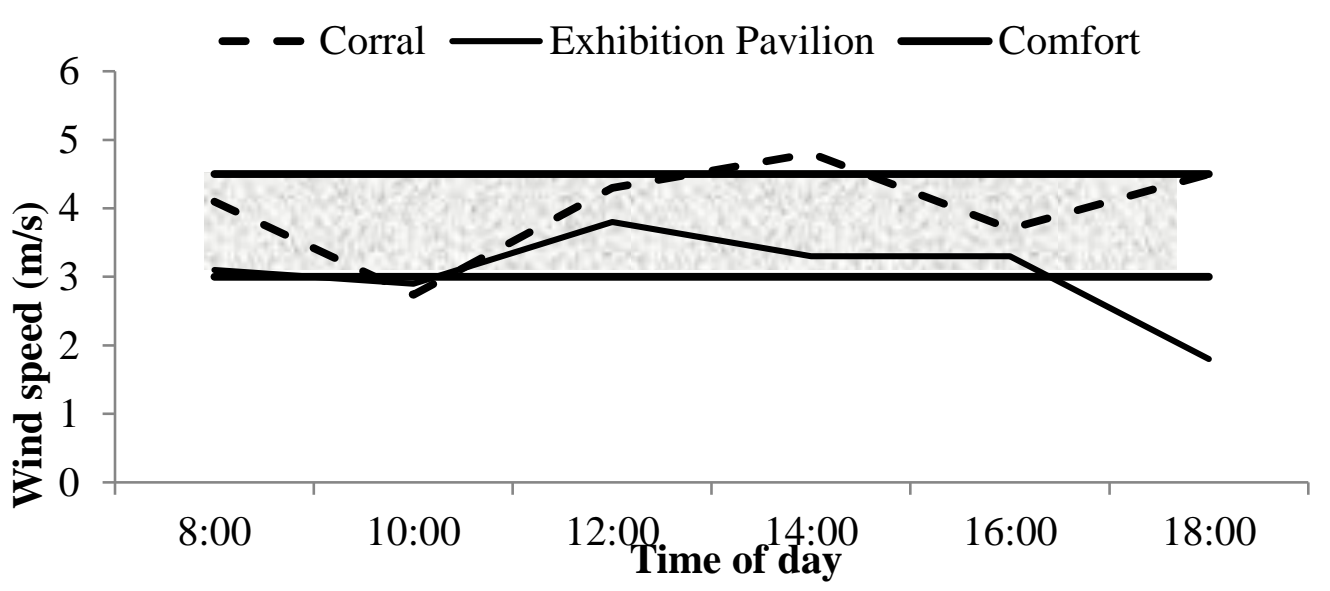

Figure 1 Mean values of the wind speed during the day in the Agricultural fair. 
Water availability and quality are important factors to be evaluated as they are essential for animal nutrition. Throughout the day the water means temperature was increasing, reaching maximum values at 14:00 in the corral and at 16:00 in the pavilion. According to Campos (2001), the animals normally prefer to drink water with a temperature between 25 and $30{ }^{\circ} \mathrm{C}$, tending to decrease the intake when water temperature is below $15^{\circ} \mathrm{C}$. Therefore, the results show that the water temperature is within the range considered suitable for cattle.

The water temperature in the corral was higher than the water temperature in the pavilion and this was due to the shading lack and surrounding landscaping lack in the corral.
The use of trees and roof coverings in the pavilions protected the animals and drinking fountains from direct solar radiation.

During the observations on the auction road, there was intense handling to facilitate the animal movement and to favor the buyers' visibility. For this, the handlers raised their voice and used wooden sticks. However, the animals did not express aggression or fear. The stay average time of the animals in the lane was of $4 \mathrm{~min}$ and $26 \mathrm{sec}$ and the noise minimum intensity verified was of $103 \mathrm{~dB}(\mathrm{~A})$ and the maximum value of $112 \mathrm{~dB}(\mathrm{~A})$. These noise values were above the tolerable maximum limit $(85 \mathrm{~dB}(\mathrm{~A}))$ for an 8-hour exposure, as can be seen in Figure 2.

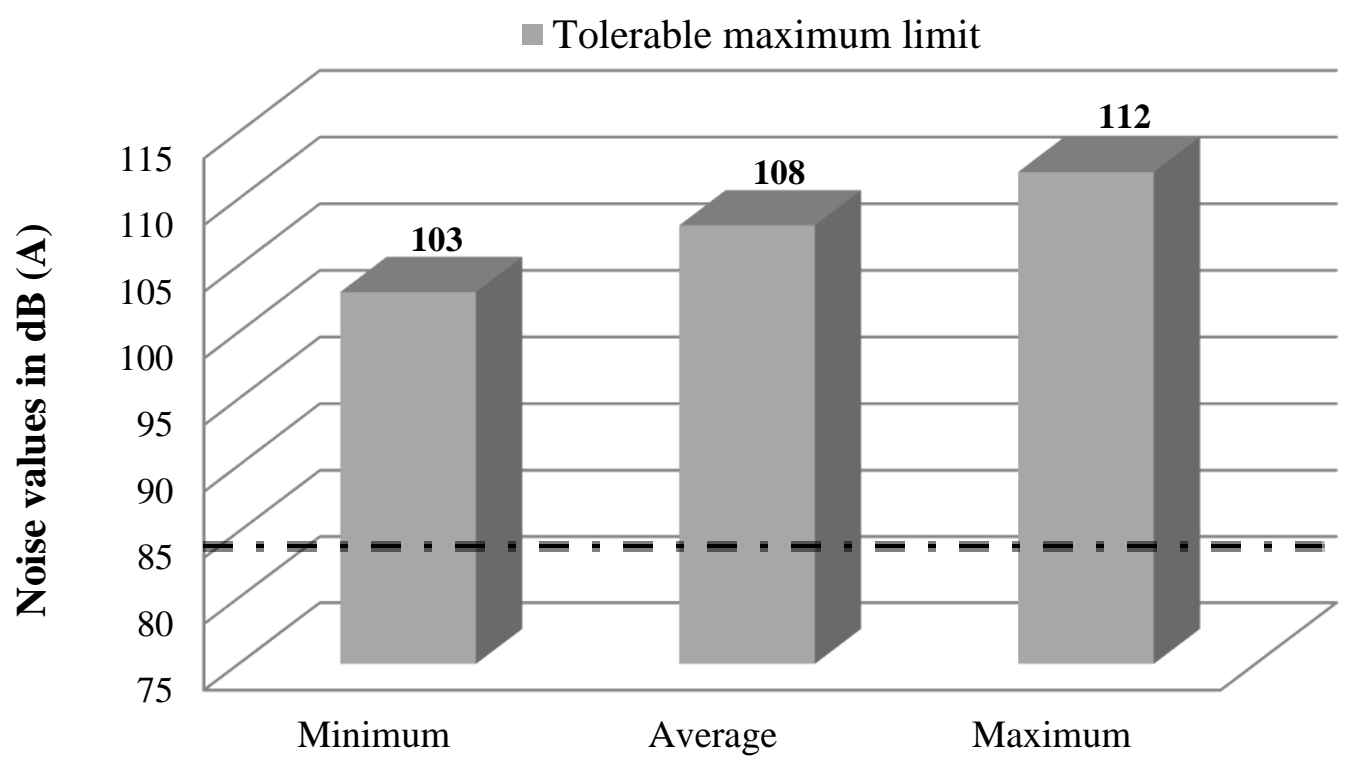

Figure 2 Average noise values compared to the reference value for comfort.

According to Lanier et al (2001), hearing is more sensitive in cattle than in humans and high noise can trigger adverse reactions, causing stressed serious damage to the auditory organs. The location with a sound level above 85 $\mathrm{dB}(\mathrm{A})$ exposes people to conversation and concentration's difficulty, and can lead to increased errors, reduced performance and hearing loss, headaches, nausea, depression, and emotional irritability. Consequently, declines in productivity and quality of the work (Carvalho et al 2012).

It is clear that the behavior adopted by the handlers is a result of cultural aspects, information and awareness lack about rational handling. However, thermal conditions where these people perform their tasks ultimately interferes with the activity performance. During the auction, there was some irritability in the handlers who drove the animals in and out of the enclosure. The high sound associated with the speed with which the work was done altered the handler's behavior and, it is believed that these factors contribute to possible aggressive actions.

\section{Conclusions}

It is concluded that, although the society has been concerned with the welfare conditions of animals and humans, it is verified that the time they stayed in the enclosure and the short duration of the agricultural fair, the rational handling of animals and facilities for workers are still in need of improvement.

The physiological varibles did not show high values, indicating that the animals were able to thermoregulate despite the uncomfortable situation caused by the transport time and accommodation site.

However, it is believed that changes in this sector will occur slowly and positively, as the farmers are becoming becoming aware on the importance of the changes, in order to improve the breeding systems and thus, to conquer new markets. 


\section{Acknowledgements}

The present work was carried out with the support of the Coordination of Improvement of Personnel of the superior level - Brazil (CAPES) - Code of financing 001. To Foundation for Research Support of the State of Minas Gerais, National Council for Scientific and Technological Development and State University of Montes Claros.

\section{References}

Azevêdo DMMR, Alves AA, Feitosa FS, Magalhães JA, Malhado OCHM (2008) Adaptabilidade de bovinos da raça pé-duro às condições climáticas do semi-árido do estado do Piauí. Archivos de Zootecnia 57:513-523.

Brief AP, Weiss HM (2002) Organizational behavior: Affect at work. Annual Review of Psychology 53:279-307.

Buffington DE, Collazo-Arocho A, Canton GH, Pitt D, Thatcher WW, Collier RJ (1981) Black globe-humidity index (BGHI) as a comfort equation for dairy cows. Transactions of the ASAE 24:711714.

Campos AT (2001) Importância da água para bovinos de leite. Revista Instrução Técnica para o Produtor de Leite 12:1518-3254.

Carvalho CCS, Souza CF, Tinôco IFF, Vieira MFA, Minette LJ (2011) Segurança, saúde e ergonomia de trabalhadores em galpões de frangos de corte equipados com diferentes sistemas de abastecimento de ração. Engenharia Agrícola 31:438-447.

Carvalho CCS, Santos TC, Silva GC, Santos LV, Moreira SJM, Botelho LFR (2014) Conforto térmico animal e humano em galpões de frangos de corte no semiárido mineiro. Revista Brasileira de Engenharia Agrícola e Ambiental 18:769-773.

Chiquitelli NM (2005) Qualidade que vem do bem-estar. Revista Cultivar Bovinos 19:25-26.

Ferreira F, Pires MFA, Martinez ML, Coelho SG, Carvalho AU, Ferreira PM, Facury Filho EJ, Campos WE (2006) Parâmetros fisiológicos de bovinos cruzados submetidos ao estresse calórico. Arquivo Brasileiro de Medicina Veterinária e Zootecnia 58:732-738.

Grandin T (1997) Assessment of stress during handling and transport. Journal of Animal Science 75:249-257.

Gregory NG, Grandin T (1998) Animal welfare and meat science. London, UK: Cabi. 254.

Hahn GL, Mader T L (1997) Heat waves in relation to thermoregulation, feeding behavior, and mortality of feedlot cattle. In: International livestock environment symposium 5, Minnesota. Proceedings... St. Joseph: ASAE. 1997. 125-129.

Kolb E (1987) Fisiologia veterinária. 4.ed. Rio de Janeiro: Guanabara Koogan, 612.

Lanier JL (2001) Note on hair whorl position and cattle temperament in the auction ring. Applied Animal Behaviour Science 73:93-101.

Marçal WS (1996) Entidades clínicas de bovinos em exposições agropecuárias. Revista da Associação Brasileira de Educação Agrícola Superior 43-50.

NR 15 (2004) Atividades e operações insalubres. In: Segurança e medicina do trabalho. São Paulo: Atlas.

NR 17 (2004) Atividades e operações insalubres. In: Segurança e medicina do trabalho. São Paulo: Atlas.
Pereira MFV (2011) Difusão da inovação, consumo e cotidiano no campo moderno - notas sobre o papel das feiras agropecuárias em Rondônia (Brasil). Radega 21:4-19.

Robinson EN (1999) Termorregulação. In: Cunningham, JG. Tratado de fisiologia veterinária. 2. ed. Rio de Janeiro: Guanabara Koogan, 427-435.

Silva GA, Souza BB, Alfaro CEP, Azevedo AS, Azevedo Neto J, Silva EMN, Silva RMN (2005) Efeito das épocas do ano e de turno sobre os parâmetros fisiológicos e seminais de caprinos no semiárido paraibano. Agropecuária Científica no Semiárido 1:7-14. 